\title{
KOMENTAR TERHADAP UNDANG-UNDANG BADAN HUKUM PENDIDIKAN DAN KESIAPAN UNY MENJADI BADAN HUKUM PENDIDIKAN
}

\author{
Anang Priyanto \\ Dosen Jurusan Pendidikan Kewarganegaraan dan Hukum FISE dan Ketua \\ Unit Konsultasi dan Bantuan Hukum UNY
}

\begin{abstract}
Pro and contra responses arises release of Act of Legal Body of Education (BHP). The emergence of the forementioned Act is mandate of Act of System of National Education. The articles of Act response completely the objections of the opposing parties against this Act. They should prosecute it through constitutional review in Court of Constitution/Mabkamah Konstitusi $(M K)$. They should prove the fundamental weaknesses of its content.

If UNY is ready to change its legal body into BHP, whole aspect of its management and conduct should be adjusted to the provisions og the Act. UNY bas already tried to anticipate the regulation through preparing the statute of University.
\end{abstract}

Keywords: BHP, Education, UNY

\section{Pendahuluan}

Disahkannya Undang-Undang Badan Hukum Pendidikan (UU BHP) banyak pihak yang pro dan kontra atas keluarnya undang-undang tersebut. Pihak yang kontra beralasan bahwa dengan UU BHP ini ada indikasi komersialisasi pendidikan karena status BHP yang diidentikkan dengan korporasi, menunjukkan lepasnya tanggung jawab pemerintah atas pembiayaan pendidikan, membatasi kesempatan rakyat kecil (berpenghasilan rendah secara ekonomi) memperoleh pendidikan yang lebih tinggi, terjadinya liberalisasi di bidang pendidikan yang dianggap tidak sesuai dengan filosofi bangsa Indonesia dan masih banyak lagi alasan yang meragukan keberadaan UU BHP. Sedangkan pihak yang pro terutama dari pihak pemerintah menganggap bahwa UU BHP sebenarnya bertujuan untuk lebih memberi kebebasan (otonomi) pada pengelolaan satuan pendidikan terbebas dari kooptasi birokrasi. Benarkah UU BHP berdampak negatif dalam dunia pendidikan di Indonesia seperti yang dituduhkan oleh kelompok yang kontra terhadap keberadaannya ataukah justru akan membawa kemajuan di dunia pendidikan kita? 
Sebenarnya mempermasalahkan BHP sudah sejak lama diperdebatkan, yaitu sejak Pasal 53 Undang-Undang Nomor 20 Tahun 2003 tentang Sistem Pendidikan Nasional (UU Sisdiknas) mengamanatkan munculnya badan hukum pendidikan, kemudian diikuti dengan munculnya Rancangan Undang-Undang (RUU) BHP yang ternnyata banyak mendapat tanggapan beragam baik melalui seminar-seminar, diskusi-diskusi ilmiah, temu ahli, public hearing berkali-kali bahkan sempat dilakukan judicial review terhadap Pasal 53 UU Sisdiknas, dan sampai-sampai RUU BHP ini telah beberapa kali mengalami perubahan, dan berakhir pada tanggal 16 Januari 2009 disahkannya RUU BHP ini oleh Presiden setelah ada kesepakatan bersama antara Pemerintah dan DPR. Dengan demikian UU BHP ini lahir dari proses yang lama dan mendalam. Oleh karena itu mempersoalkan BHP saat ini merupakan sesuatu hal yang sudah berulang-ulang dipersoalkan. Jadi perdebatannya sudah dianggap matang, sehingga yang terpenting saat ini adalah bagaimana sebagai warga negara yang baik ikut mengawal jalannya UU BHP ini. Pertama-tama yang dapat dilakukan adalah dengan mencermati isi dari sétiap pasal yang ada dalam UU BHP dan kemungkinan pelaksanaannya dalam pratek atau dalam istilah hukumnya mencermati adakah ketidak serasian antara law in the book dan law in action.

Sebagai anggota komunitas Universitas Negeri Yogyakarta (UNY) ada baiknya mendiskusikan bersama kesiapan UNY menjadi BHP terlepas dari pro dan kontra atas keluarnya UU BHP. Yang jelas UNY sebagai salah satu universitas di negeri ini yang berstatus universitas milik pemerintah, suka atau tidak suka harus melaksanakan amanat UU BHP ini. Dengan demikian UNY mau tidak mau, suka atau tidak suka harus melaksanakan segala isi UU BHP. Sudah siapkah UNY menjadi BHP? Untuk menjawab pertanyaan ini sebenarnya akan lebih tepat dilakukan oleh Pejabat Pimpinan UNY yang masih aktif, karena dari beliaulah data-data kesiapan lebih akurat diperoleh, tetapi tidak ada salahnya kita coba untuk menjawab kesiapan UNY ini dengan mengkaji isi UU BHP terutama yang berhubungan dengan kekuatiran-kekuatiran dari kelompok yang tidak setuju UU BHP, dan kemungkinan dampak yang ditimbulkan dalam pelaksanaannya.

\section{Apa itu BHP?}

BHP adalah singkatan dari Badan Hukum Pendidikan. Namun BHP dengan badan hukum pendidikan (buruf awalkata kecil) memiliki arti yang berbeda. Badan Hukum Pendidikan merupakan nama jenis, sedangkan badan hukum pendidikan merupakan nama diri. Jadi badan hukum pendidikan itu salah satunya adalah BHP. 
Istilah badan hukum pendidikan sebenarnya muncul pertama kali saat disusunnnya Undang-undang Sistem Pendidikan Nasional untuk melindungi universitas-universitas Badan Hukum Milik Negara (BHMN) yang secara legal dipertanyakan karena tidak mendapat landasan hukum yang kuat. Namun di samping itu keberadaan badan hukum pendidikan itu juga dilandasi adanya pemikiran bahwa sebuah perguruan tinggi atau universitas memiliki arti sebagai science center, sebagai pusat ilmu pengetahuan. Sebagai pusat ilmu pengetahuan berarti tempat melakukan pengembangan ilmu yang memiliki otonomi keilmuan dalam pengelolaannya agar tetap betkelanjutan. Kegiatan utama dalam perguruan tinggi adalah riset dan pendidikan termasuk pengabdian kepada masyarakat.

\section{Beberapa Ketentuan yang ada dalam UU BHP}

1. Keluarnya UU BHP didasarkan atas pertimbangan: ${ }^{1}$

a. untuk mewujudkan fungsi dan tujuan pendidikan nasional berdasarkan Pancasila dan UUD 1945

b. sebagai wujud semangat reformasi di bidang pendidikan yang terkandung dalam Pasal 31 Undang-Undang Dasar Negara Republik Indonesia Tahun 1945;

c. adanya prinsip penyelenggaraan pendidikan dalam reformasi pendidikan, yaitu pendidikan diselênggarakan secara demokratis dan berkeadilan serta tidak diskriminatif dengan menjunjung tinggi hak asasi manusia, nilai keagamaan, nilai kultural, dan kemajemukan bangsa, dan pendidikan diselenggarakan dengan memberdayakan semua komponen masyarakat melalui peran serta dalam penyelenggaraan dan pengendalian mutu layanan pendidikan.

d. sebagai amanat Undang-Undang Sistem Pendidikan Nasional (UndangUndang Nomor 20 Tahun 2003) tentang perlunya pelaksanaan manajemen pendidikan berbasis sekolah/madrasah pada jenjang pendidikan dasar dan menengah, serta otonomi perguruan tinggi pada jenjang pendidikan tinggi.

2. Diakomodasikannya berbagai bentuk badan hukum pendidikan dalam dua jenis yaitu BHP Penyelenggara dan badan hukum pendidikan satuan pendidikan. ${ }^{2}$

1) Lihat Bagian Menimbang dan Penjelasan Umum Undang-Undang Nomor 9 Tahun 2009 tentang Badan Hukum Pendidikan.

2) Pasal 5 sampai dengan Pasal 13 UU BHP. 
Hal ini menunjukan bahwa UU BHP telah menampung aspirasi partisipasi masyarakat dalam pengelolaan pendidikan yang sudah ada dengan tidak memaksakan perubahan bentuk ke BHP.

3. BHP berfungsi memberikan pelayanan pendidikan formal kepada peserta didik, dan bertujuan memajukan pendidikan nasional dengan menerapkan management berbasis sekolah/madrasah pada jenjang pendidikan dasar dan menengah dan otonomi perguruan tinggi pada jenjang pendidikan tinggi. ${ }^{3}$ Dari ketentuan ini UU BHP memberi peluang kepada setiap perguruan tinggi mengelola secara mandiri lembaganya tanpa campur tangan birokrasi pemerintah terutama pada perguruan tinggi milik pemerintah. Aturan birokrasi pemerintahan yang selama ini kurang tepat diberlakukan di lingkungan perguruan tinggi yang dianggap dapat menghambat kreatifitas, inovasi dan akuntabilitas perguruan tinggi.

4. Pengelolaan BHP didasarkan pada prinsip nirlaba, artinya kegiatan yang dilakukan dengan tujuan utamanya tidak untuk mencari keuntungan. ${ }^{4}$

Dengan mencermati ketentuan di atas nampak bahwa pengelolaan BHP tidaklah dibenarkan untuk mencari keuntungan dari para pendirinya. Oleh karenanya BHP harus dijauhkan dari sifat komersial dalam pengelolaannya.

5. Pemerintah dengan kewenangannya bertanggungjawab dalam penyediaan dana pendidikan sebagaimana diatur dalam Pasal 31 ayat (4) UUD $1945 .^{5} \mathrm{Hal}$ ini mennunjukkan bahwa Pemerintah tidak bisa lepas tanggungjawab atas penyediaan dana bagi pendidikan.terutama penyediaan dana $20 \%$ dari anggaran negara untuk memajukan pendidikan nasional. Disamping itu BHP harus menyediakan anggaran untuk membantu peserta didik WNI yang tidak mampu membiayai pendidikannya dalam bentuk beasiswa, bantuan biaya pendidikan, kredit mahasiswa, dan/atau pemberian pekerjaan kepada mahasiswa.

6. BHP wajib menjaring dan menerima WNI yang memiliki potensi akademik tinggi dan kurang mampu secara ekonomi minimal 20\% dari keseluruhan jumlah peserta didik yangsbaru, dan wajib mengalokasikan bantuan biaya pendidikan bagi mereka. ${ }^{6}$ Dengan demikian UU BHP menjamin bagi WNI yang kurang mampu secara ekonomi untuk memperoleh pendidikan yang lebih tinggi. Jadi bagi rakyat miskin secara ekonomi tetap menjadi perhatian

3) Pasal 2 dan Pasal 3 jo Pasal 38 UU BHP

4) Pasal 4 UU BHP.

5) Pasal 40 dan Pasal 41 UU BHP

g) Pasal 46 UU BHP 
100 Anang Priyanto, Komentar terhadap Undang-Undang Badan Hukum Pendidikan dan Kesiapan UNY menjadi Badan Hukum Pendidikan

bagi badan hukum pendidikan perguruan tinggi untuk menyediakan fasilitas terhadapnya.

7. BHP harus melakukan pertanggungjawaban kepada masyarakat atas penyelenggaraan pendidikan (akuntabilitas publik). ${ }^{7} \mathrm{Hal}$ ini menunjukkan bahwa segala penyelenggaraan pendidikan yang dilakukan oleh bbadan hukum pendidikan harus dapat dipertanggungjawabkan kepada masyarakat, sehingga segala pelaksanaannya harus benar-benar transparan dan profesional serta bermutu.

8. Pelanggaran terhadap prinsip nirlaba dan komersialisasi badan hukum pendidikan dapat diancam sanksi pidana. ${ }^{8}$ Dengan demikian jelaslah bahwa badan hukum pendidikan tidak diperbolehkan menyelenggarakan pendidikan untuk mencari keuntungan dan bersifat komersial.

Dari beberapa ketentuan yang ada dalam UU BHP di atas dapat menjawab kesan negatif terhadap isi dari UU BHP tersebut. Lahirnya UU BHP merupakan amanat dari UU Sisdiknas, dan apabila UU BHP ini tetap dianggap menjadi kendala oleh pihak-pihak yang kontra atas keberadaannya maka pihak-pihak tersebut harus dapat membuktikan kelemahan-kelemahan isi dari UU BHP ini melalui uji material ke Mahkamah Konstitusi seperti yang pernah dilakukan oleh Asosiasi BPPTSI, YPLP-PGRI dan Komdik KWIN saat mengajukan uji material terhadap Pasal 53 ayat (1) UU Sisdiknas kepada Mahkamah Konstitsi pada tanggal 26 September 2006, ${ }^{2}$ dan berakhir dengan ditolaknya permohonan tersebut.

Pihak-pihak yang keberatan atas keberadaan UU BHP paling tidak harus dapat membuktikan bahwa apa yang terkandung dalam UU BHP sangat bertentangan dengan aspek filosofis, aspek sosiologis maupun aspek yuridis. Pembuktian pada aspek filosofis mengarah pada filosofis dari pengelolaan pendidikan di Indonesia, yakni bahwa pendidikan adalah tanggung jawab negara yang terbuka bagi partisipasi masyarakat. UU BHP sudah mengakomodasi hal tersebut dan tampak dari beberapa ketentuan pasal-pasalnya antara lain Pasal 40, Pasal 41 dan Pasal 44 UU BHP.

7) Pasal 47 UU BHP.

8) Pasal 63 UU BHP.

9) Thomas Suyatno (2007). Liberalisasi Pendidikan dan Lonceng Kematian Lembaga-Lembaga Pendidikan Indonesia, makalah seminar Nasional "Neo Liberalisme Pendidikan" 28 Juli 2007 di UGM Yogyakarta. 
Pasal 40

(1) Sumber dana untuk pendidikan formal yang diselenggarakan badan hukum pendidikan ditetapkan berdasarkan prinsip keadilan, kecukupan, dan kebetlanjutan.

(2) Pendanaan pendidikan formal yang diselenggarakan badan hukum pendidikan menjadi tanggung jawab bersama antara Pemerintah, pemerintah daerah, dan masyarakat sesuai dengan ketentuan peraturan perundang-undangan.

(3) Badan hukum pendidikan menyediakan anggaran untuk membantu peserta didik Warga Negara Indonesia yang tidak mampu membiayai pendidikannya, dalam bentuk:
a. beasiswa;
b. bantuan biaya pendidikan;
c. kredit mahasiswa; dan/atau
d. pemberian pekerjaan kepada mahasiswa.

(4) Pemerintah dan pemerintah daerah sesuai dengan kewenangannya bertanggung jawab dalam penyediaan dana pendidikan sebagaimana diatur dalam Pasal 31 ayat (4) Undang-Undang Dasar Negara Republik Indonesia Tahun 1945.

(5) Dana pendidikan sebagaimana dimaksud pada ayat (4) yang disalurkan dalam bentuk hibah sesuai dengan ketentuan peraturan perundangundangan untuk badan hukum pendidikan diterima dan dikelola oleh pemimpin oxgan pengelola pendidikan.

- Pasal 41

(1) Pemerintah dan pemerintah daerah sesuai dengan kewenangannya menanggung seluruh biaya pendidikan untuk BHPP dan BHPPD dalam menyelenggarakan pendidikan dasar untuk biaya operasional, biaya investasi, beasiswa, dan bantuan biaya pendidikan bagi peserta didik, berdasarkan standar pelayanan minimal untuk mencapai Standar Nasional Pendidikan.

(2) Pemerintah, pemerintah daerah, dan masyarakat dapat memberikan bantuan sumberdaya pendidikan kepada badan hukum pendidikan.

(3) Pemerintah dan pemerintah daerah sesuai dengan kewenangannya menanggung seluruh biaya investasi, beasiswa, dan bantuan biaya pendidikan pada BHPP dan BHPPD yang menyelenggarakan pendidikan menengah berdasarkan estándar pelayanan minimal untuk mencapai Standar Nasional Pendidikan. 
102 Anang Priyanto, Komentar terhadap Undang-Undang Badan Hukum Pendidikan dan Kesiapan UNY menjadi Badan Hukum Pendidikan

(4) Pemerintah dan pemerintah daerah sesuai dengan kewenangannya menanggung paling sedikit $1 / 3$ (sepertiga) biaya operasional pada BHPP dan BHPPD yang menyelenggarakan pendidikan menengah berdasarkan standar pelayanan minimal untuk mencapai Standar Nasional Pendidikan.

(5) Pemerintah bersama-sama dengan BHPP menanggung seluruh biaya investasi, beasiswa, dan bantuan biaya pendidikan pada BHPP yang menyelenggarakan pendidikan tinggi berdasarkan standar pelayanan minimal untuk mencapai Standar Nasional Pendidikan.

(6) Pemerintah bersama-sama dengan BHPP menanggung paling sedikit $1 /$ 2 (seperdua) biaya operasional, pada BHPP yang menyelenggarakan pendidikan tinggi berdasarkan standar pelayanan minimal untuk mencapai Standar Nasional Pendidikan.

(7) Peserta didik yang ikut menanggung biaya penyelenggaraan pendidikan harus menanggung biaya tersebut sesuai dengan kemampuan peserta didik, orang tua, atau pihak yang bertanggung jawab membiayainya.

(8) Biaya penyelenggaraan pendidikan sebagaimana dimaksud pada ayat (7) yang ditanggung oleh seluruh peserta didik dalam pendanaan pendidikan menengah berstandar pelayanan minimal untuk mencapai Standar Nasional Pendidikan pada BHPP atau BHPPD paling banyak $1 / 3$ (sepertiga) dari biaya operasional.

(9) Biaya penyelenggaraan pendidikan sebagaimana dimaksud pada ayat (7) yang ditanggung oleh seluruh peserta didik dalam pendanaan pendidikan tinggi berstandar pelayanan minimal untuk mencapai Standar Nasional Pendidikan pada BHPP paling banyak 1/3 (sepertiga) dari biaya operasional.

(10) Dana pendidikan dari Pemerintah dan pemerintah daerah sesuai dengan kewenangannya pada badan hukum pendidikan diberikan dalam bentuk hibah sesuai dengan ketentuan peraturan perundangundangan.

- Pasal 44

(1) Pemerintah dan pemerintah daerah sesuai dengan kewenangannya menanggung dana pendidikan untuk BHPM dan BHP Penyelenggara, dalam menyelenggarakan program wajib belajar pendidikan dasar, untuk biaya operasional dan beasiswa, serta bantuan biaya investasi dan bantuan biaya pendidikan bagi peserta didik sesuai dengan estándar pelayanan minimal untuk mencapai Stándar Nasional Pendidikan.

(2) Pemerintah dan/atau pemerintah daerah memberikan bantuan dana pendidikan pada BHPM dan BHP Penyelenggara. 
(3) Dana pendidikan dari Pemerintah dan pemerintah daerah sesuai dengan kewenangannya pada badan hukum pendidikan diberikan dalam bentuk hibah sesuai dengan ketentuan peraturan perundangundangan.

Sedangkan aspek sosiologis terkait pada kesesuaian dengan kondisi masyarakat kita pada keterlibatannya dalam penyelenggaraan pendidikan, dan hal ini juga nampak dari dibukanya ragam bentuk badan hukum pendidikan yang sudah ada di masyarakat sebagaimana diatur dalam Pasal 5 sampai dengan Pasal 13 UU BHP. - Pasal 5

(1) Jenis badan hukum pendidikan terdiri atas BHP Penyelenggara dan badan hukum pendidikan satuan pendidikan.

(2) BHP Penyelenggara merupakan jenis badan hukum pendidikan pada penyelenggara, yang menyelenggarakan 1 (satu) atau lebih satuan pendidikan formal.

(3) Badan hukum pendidikan satuan pendidikan merupakan jenis badan hukum pendidikan pada satuan pendidikan formal.

- Pasal 6

(1) Bentuk badan hukum pendidikan satuan pendidikan terdiri atas BHPP, BHPPD, dan BHPM.

(2) BHPP, BHPPD, dan BHPM hanya mengelola 1 (satu) satuan pendidikan formal.

- Pasal 7

(1) BHPP didirikan oleh Pemerintah dengan peraturan pemerintah atas usul Menteri.

(2) BHPPD didirikan oleh pemerintah daerah dengan peraturan gubernur atau peraturan bupati/walikota.

(3) BHPM didirikan oleh masyarakat dengan akta notaris yang disahkan oleh Menteri.

- Pasal 8

(1) Satuan pendidikan dasar dan menengah yang telah didirikan oleh Pemerintah atau pemerintah daerah dan telah memenuhi Standar Nasional Pendidikan dan berakteditasi A berbentuk badan hukum pendidikan.

(2) Satuan pendidikan tinggi yang telah didirikan oleh Pemerintah berbentuk badan hukum pendidikan. 
104 Anang Priyanto, Komentar terhadap Undang-Undang Badan Hukum Pendidikan dan Kesiapan UNY menjadi Badan Hukum Pendidikan

(3) Yayasan, perkumpulan, atau badan hukum lain sejenis yang telah menyelenggarakan satuan pendidikan dasar, pendidikan menengah, dan/ atau pendidikan tinggi, diakui sebagai BHP Penyelenggara.

- Pasal 9

(1) BHP Penyelenggara sebagaimana dimaksud dalam Pasal 8 ayat (3) dapat menyelenggarakan lebih dari 1 (satu) satuan pendidikan.

(2) BHP Penyelenggara dapat mengubah bentuk satuan pendidikannya menjadi BHPM.

- Pasal 10

Satuan pendidikan yang didirikan setelah Undang-Undang ini berlaku, wajib berbentuk badan hokum pendidikan.

- Pasal 11

(1) Pendirian badan hukum pendidikan harus memenuhi persyaratan bahwa badan hukum pendidikan yang akan didirikan tersebut mempunyai:

a. pendiri;

b. tujuan di bidang pendidikan formal;

c. struktur organisasi; dan

d. kekayaan sendiri yang terpisah dari kekayaan pendiri.

(2) Jumlah kekayaan yang dipisahkan oleh pendiri sebagai kekayaan badan hukum pendidikan sebagaimana dimaksud pada ayat (1) huruf d,harus memadai untuk biaya investasi dan mencukupi untuk biaya operasional badan hokum pendidikan dan ditetapkan dalam anggaran dasar.

(3) Dalam waktu paling lama 2 (dua) tahun setelah BHP Satuan Pendidikan berdiri, pendiri harus membentuk organ-organ lainnya sesuai dengan ketentuan dalam undang-undang ini.

- Pasal 12

(1) Peraturan pemerintah, peraturan gubernur atau bupati/walikota, atau akta notaris sebagaimana dimaksud dalam Pasal 7 ayat (1), ayat (2), dan ayat (3) memuat anggaran dasar BHPP, BHPPD, atau BHPM dan keterangan lain yang dianggap perlu.

(2) Penyusunan anggaran dasar BHPP, BHPPD, atau BHPM dilakukan oleh pendiri BHPP, BHPPD, atau BHPM.

(3) Pengaturan tentang perubahan anggaran dasar BHPP, BHPPD, dan BHPM ditetapkan dalam anggaran dasar. 
(4) Anggaran dasar BHPP, BHPPD, dan BHPM sebagaimana dimaksud pada ayat (1) paling sedikit memuat:

a. nama dan tempat kedudukan;

b. tujuan;

c. ciri khas dan ruang lingkup kegiatan;

d. jangka waktu berdiri;

e. struktur organisasi serta nama dan fungsi setiap organ;

f. susunan, tata cara pembentukan, kriteria dan persyaratan, pengangkatan serta \pemberhentian anggota, serta pembatasan masa keanggotaan organ;

g. tata cara pengangkatan dan pemberhentian pimpinan serta masa jabatan pimpinan organ;

h. susunan, tata cara pembentukan, kriteria dan persyaratan, pengangkatan serta pemberhentian, serta pembatasan masa jabatan pimpinan organ;

i. jumlah kekayaan yang dipisahkan oleh pendiri sebagai kekayaan awal;

j. sumber daya;

k. tata cara penggabungan atau pembubaran;

1. perlindungan terhadap pendidik, tenaga kependidikan, dan peserta didik;

m. ketentuan untuk mencegah terjadinya kepailitan;

n. tata cara pengubahan anggaran dasar; dan

o. tata cara penyusunan dan pengubahan anggaran rumah tangga.

- Pasal 13

(1) Status sebagai BHPP berlaku mulai tanggal Peraturan Pemerintah tentang pendirian BHPP ditetapkan oleh Presiden.

(2) Status sebagai BHPPD berlaku mulai tanggal peraturan gubernur/bupati/ walikota tentang pendirian BHPPD ditetapkan oleh gubernur/bupati/ walikota sesuai dengan kewenangan masing-masing.

(3) Status sebagai BHPM berlaku mulai tanggal akta notaris tentang pendirian BHPM disahkan oleh Menteri.

(4) Perubahan anggaran dasar BHPP, BHPPD, atau BHPM mengenai hal yang diatur dalam Pasal 12 ayat (4) huruf a, huruf b, huruf c, huruf i, huruf $j$, huruf $k$, huruf 1 , dan huruf $m$ disahkan oleh Menteri.

(5) Perubahan anggaran dasar BHPP, BHPPD, atau BHPM yang tidak menyangkut hal-hal sebagaimana dimaksud pada ayat (4) diberitahukan kepada Menteri. 
106 Anang Priyanto, Komentar terhadap Undang-Undang Badan Hukum Pendidikan dan Kesiapan UNY menjadi Badan Hukum Pendidikan

Aspek yuridis berhubungan dengan prosedur dan landasan hukum penyusunan UU BHP itu sendiri dan nampak bahwa penyusunan UU BHP sebagaimana dalam pertimbangannya telah diuraikan lahirnya UU BHP merupakan amanat dari UU Sisdiknas, juga dengan prosedur penyusunan yang sesuai dengan ketentuan undang-undang yaitu Undang-Undang Nomor 10 Tahun 2004 tentang Pembentukan Peraturan Perundang-undangan.

Sebenarnya yang terpenting adalah bahwa pengaturan BHP semestinya tidak merupakan wujud ikut-ikutan atau ketakutan pada dampak globalisasi yang berimbas pada kemampuan berkompetisi di dunia global. Pengelolaan pendidikan di negeri ini seharusnya lebih menunjukkan pada ciri pengelolaan pendidikan yang berasaskan Pancasila yang berbeda dengan negara-negara lain. Para ahli pendidikan kita dan para pengambil kebijakan pendidikan sering tidak merasa percaya diri untuk melahirkan idea-idea, konsep-konsep, gagasan-gasasan dan teoriteori yang berciri pada masyarakat Pancasila. Mereka lebih suka untuk melahirkan kebijakan (dalam bentuk undang-undang misalnya) untuk melakukan rekayasa sosial dalam upaya perubahan masyarakat dengan meninggalkan karakter bangsa. Hal inilah yang harus selalu kita waspadai.

\section{Kesiapan UNY menjadi BHP}

Dengan adanya UU BHP secara yuridis harus berlaku sejak diundangkan, dan hal ini tentunya juga berdampak pada UNY sebagai perguruan tinggi milik pemerintah yang harus melaksanakan segala ketentuan yang ada dalam UU BHP tersebut. Namun dalam ketentuan Pasal 65 UU BHP telah diuraikan bahwa satuan pendidikan yang diselenggarakan oleh Pemerintah sebelum UU BHP berlaku diakui keberadaannya dan tetap dapat menyelenggarakan pendidikan formal harus mengubah bentuk dan menyesuaikan tata kelolanya sebagai BHP Pemerintah menurut UU BHP, paling lambat 4 (empat) tahun sejak UU BHP diundangkan. Dengan demikian perubahan bentuk UNY menjadi UNY pola BHP paling lambat harus sudah dilakukan 4 (empat) tahun sejak diundangkannya UU BHP ini, jadi paling lambat pada tahun 2013 UNY sudah menjadi universitas BHP.

Apabila UNY siap menjadi pola BHP maka segala pengelolaan universitas harus ditata sedemikian rupa disesuaikan dengan ketentuan yang ada dalam UU BHP. Sejak dikumandangkannya bentuk BHP, UNY sudah mencoba mengantisipasi dengan mempersiapkan Anggaran Dasar dan Anggaran Rumah Tangga (AD-ART).

Sejak awal munculnya RUU BHP dibentuklah Tim BHP UNY untuk mempersiapkan Anggaran Dasar, dan sejak saat itulah Tim BHP UNY mulai 
bekerja dengan menyusun draf-draf Anggaran Dasar dengan mengacu pada RUU BHP yang ada saat itu, dan menambah bahan acuan disamping Statuta UNY dan OTK UNY juga AD-ART dari universitas-universitas BHMN (UGM, UNAIR, UPI). Oleh karena itulah draf AD-ART BHP UNY nampaknya lebih condong pada konsep badan hukum pendidikan BHMN dengan organ-organ di dalamnya seperti MWA, Dewan Audit, Senat Akademik, Dewan Guru Besar, Pimpinan, Unsur Pelaksana Akademik, Unsur Pelaksana Administrasi, Unsur Penujang Akademik dan Devisi (draf terakhir Anggaran Dasar 9 Januari 2007).

Dengan hadirnya UU BHP yang telah disahkan oleh Presiden RI maka draf AD-ART BHP UNY perlu beberapa penyesuaian dengan isi UU BHP ini dikarenakan penyusunan draf itu didasarkan pada RUU BHP yang masih mengalami beberapa perubahan saat itu. Penyesuaian terutama pada persoalan ketentuan yang ada pada organ-organ universitas, persoalan pengaturan kekayaan dan pendapatan, juga persoalan pendanaan dan bantuan biaya pendidikan yang mewajibkan minimal 20\% diberikan kepada peserta didik yang secara ekonomi kurang mampu tetapi memiliki potensi akademik yang tinggi. Tidak kalah pentingnya pula dalam menyongsong UNY pola BHP adalah civitas akademika UNY haruslah memiliki kesamaan persepsi dan konsep tentang badan hukum pendidikan, karena banyak dosen, mahasiswa dan tenaga administrasi UNY yang memiliki kesan negatif terhadap badan hukum pendidikan ini.

\section{Penutup}

Undang-Undang Nomor 9 Tahun 2009 tentang Badan Hukum Pendidikan merupakan produk amanat Undang-Undang Nomor 20 Tahun 2003 tentang Sistem Pendidikan Nasional yang dianggap telah memenuhi aspek filosofis, sosiologis maupun aspek yuridis. Namun UU BHP ini belum diketahui efectivitas berlakunya karena baru saja diundangkan. Oleh karena itu perlu pengawalan dalam pelaksanaannya terutama dari kelompok agen perubahan khususnya mahasiswa dan para kelompok independent pengamat pendidikan agar pelaksanan UU BHP ini benar-benar memenuhi apa yang dinyatakan sesuai isi UU BHP tersebut.

Para pelaku pendidikan, dan para pengelola pendidikan harus bennar-benar mempersiapkan diri menyongsong dilaksänakannya UU BHP pada satuan pendidikan yang bersangkutan masing-masing, karena idealisme yang ada dalam UU BHP dapat berdampak pada sanksi yang berat jika dalam pelaksanaannya terjadi penyimpangan. $\left(^{*}\right)$ 
108 Anang Priyanto, Komentar terhadap Undang-Undang Badan Hukum Pendidikan dan Kesiapan UNY menjadi Badan Hukum Pendidikan

\section{Daftar Pustaka}

H.A.S. Natabaya (2006), Sistem Peraturan Perundang-undangan Indonesia, Mahkamah Konstitusi Republik Indonesia, Jakarta.

Maruarar Siahaan (2006), Hukum Acara Mabkamah Konstitusi Republik Indonesia, Mahkamah Konstitusi Republik Indonesia, Jakarta.

Soerjono Soekanto dan Mustafa Abdullah (1982), Sosiologi Hukum Dalam Masyyarakat, CV Rajawali, Jakarta

Thomas Suyatno (2007). Liberalisasi Pendidikan dan Lonceng Kematian LembagaLembaga Pendidikan Indonesia, makalah seminar Nasional "Neo Liberalisme Pendidikan" 28 Juli 2007 di UGM Yogyakarta. 